Biochimica et Biophysica Acta, 620 (1980) 332-337

(c) Elsevier/North-Holland Biomedical Press

BBA Report

BBA 51297

\title{
CARDIOLIPIN, A MAJOR PHOSPHOLIPID OF GRAM-POSITIVE BACTERIA THAT IS NOT READILY EXTRACTABLE
}

\section{M.H. FILGUEIRAS and J.A.F. OP DEN KAMP*}

Biochemisch Laboratorium, Rijksuniversiteit Utrecht, Padualaan 8, 3584 CH Utrecht (The Netherlands)

(Received June 18th, 1980)

Key words: Cardiolipin; Phospholipid extraction; (B. megaterium)

Extraction of phospholipids from stationary phase grown cells of the Gram ${ }^{+}$bacteria, Bacillus megaterium, Bacillus subtilis, Bacillus cereus and Micrococcus lysodeikticus was found to be incomplete with various commonly used extraction procedures. Phosphatidylglycerol and phosphatidylethanolamine were readily extracted but up to $95 \%$ of the cardiolipin appeared to be retained within the cell residue. Extraction of the cardiolipin could be slightly enhanced by increasing the temperature or the acidity of the extraction solutions but complete extraction was obtained only after lysozyme treatment of intact cells or cell residues remaining after extraction. In addition complete extraction could be observed in the case of cells harvested in the early logarithmic phase. Freeze-fracture electron microscopy was carried out on the cell residue remaining after extraction of all phospholipids except cardiolipin. A fracture plane through the plasma membrane could not be observed anymore. Instead fracture planes through lipid vesicles were observed. These vesicles reside within the remnants of the cyloplasm and consist most likely of the non-extracted cardiolipin.

The cytoplasmic membranes of $\mathrm{Gram}^{+}$bacteria contain cardiolipin, phosphatidylglycerol and, in some organisms, phosphatidylethanolamine as the major phospholipids [1]. The relative amounts in which these phospholipids occur, vary from one organism to another. In addition, substantial variations in phospholipid composition have been reported for a single organism. In part, this can be ascribed to different growth conditions (medi$\mathrm{um}, \mathrm{pH}$, temperature, growth phase) and furthermore strain differences can be involved [2]. However, some of the reported phospholipid compositions

*To whom correspondence should be addressed. 
TABLE I

EXTRACTION OF PHOSPHOLIPIDS FROM VARIOUS GRAM ${ }^{+}$BACTERIA

Cells and protoplasts were obtained as described in the text. The cell residue remaining after a Bligh and Dyer extraction was dried under nitrogen, suspended in buffer, treated with lysozyme as described in the text and extracted once more. The data are expressed as percentages of total $\left[{ }^{32} \mathrm{P}\right]$ phospholipid present in lipid extracts from protoplasts. It is assumed that all of the phospholipid is extracted from protoplasts.

\begin{tabular}{llll}
\hline & Protoplasts & Whole cells & $\begin{array}{l}\text { Cell residue after } \\
\text { lysozyme treatment }\end{array}$ \\
\hline B. megaterium & 100 & 65 & 35 \\
B. subtilis & 100 & 60 & 40 \\
B. cereus & 100 & 87 & 13 \\
M. lysodeikticus & 100 & 61 & 39 \\
\hline
\end{tabular}

differ in an extreme way which can best be illustrated by a short summary of the data obtained with $B$. megaterium. The published values for the cardiolipin content of $B$. megaterium vary from a few percent [3-6] to 12\% [7] and even up to $57 \%$ [8]. During a recent study on the phospholipid localization in the membrane of $B$. megaterium [9] we used the same strain as before [3] but found a cardiolipin content of $45 \%$ instead of a few percent. The explanation for these discrepancies is offered by the data presented here. In all cases in which high amounts of cardiolipin were found, lipid extraction was carried out after removal of the cell wall whereas extraction of whole cells results in a low recovery of cardiolipin.

B. megaterium (MK 10D), B. subtilis (strain Marburg) and non-identified strains of $B$. cereus and $M$. lysodeikticus were grown under continuous aeration at $37^{\circ} \mathrm{C}$ in a medium containing $1 \%$ peptone, $1 \%$ yeast extract, $0.5 \%$ $\mathrm{NaCl}$ and $0.04 \% \mathrm{Na}_{2} \mathrm{HPO}_{4}, \mathrm{pH} 7.2$. Routinely $300 \mu \mathrm{Ci}\left[{ }^{32} \mathrm{P}\right]$ phosphate was added per 1 medium. Cells were harvested after $16 \mathrm{~h}$ of growth by centrifugation, washed with $10 \mathrm{mM} \mathrm{K}$-phosphate buffer, $\mathrm{pH} 7.5$, and suspended in the same buffer. For the preparation of protoplasts, cells were suspended in this buffer containing in addition $15 \mathrm{mM} \mathrm{MgCl}_{2}$ and $0.4 \mathrm{M}$ sucrose. Lyso-

\section{TABLE II}

NATURE OF PHOSPHOLIPIDS EXTRACTED FROM WHOLE CELLS, PROTOPLASTS AND CELL RESIDUE FROM B. MEGATERIUM

Lipid extracts were analyzed by thin-layer chromatography as described before [9]. Spots were visualized with $\mathrm{I}_{2}$, scraped off and ${ }^{32} \mathrm{P}$ was counted in a Packard liquid scintillation counter. Data are expressed as percentages of the total [ ${ }^{32} \mathrm{P}$ ]phospholipid present in lipid extracts from protoplasts. Some discrepancy is noted between total phosphatidylglycerol and cardiolipin contents, which is due to a gradual conversion of phosphatidylglycerol into cardiolipin during protoplast formation. The other phospholipid fraction mainly consists of glucosaminylphosphatidylglycerol.

\begin{tabular}{lrrl}
\hline & Protoplasts & Whole cells & $\begin{array}{l}\text { Cell residue after } \\
\text { lysozyme treatment }\end{array}$ \\
\hline Total phospholipid & 100 & 65 & 35 \\
Cardiolipin & 40 & 4 & 33 \\
Phosphatidylgly ccrol & 40 & 41 & 2 \\
Phosphatidylethanolamine & 16 & 16 & \pm \\
Other & 4 & 4 & \pm \\
\hline
\end{tabular}




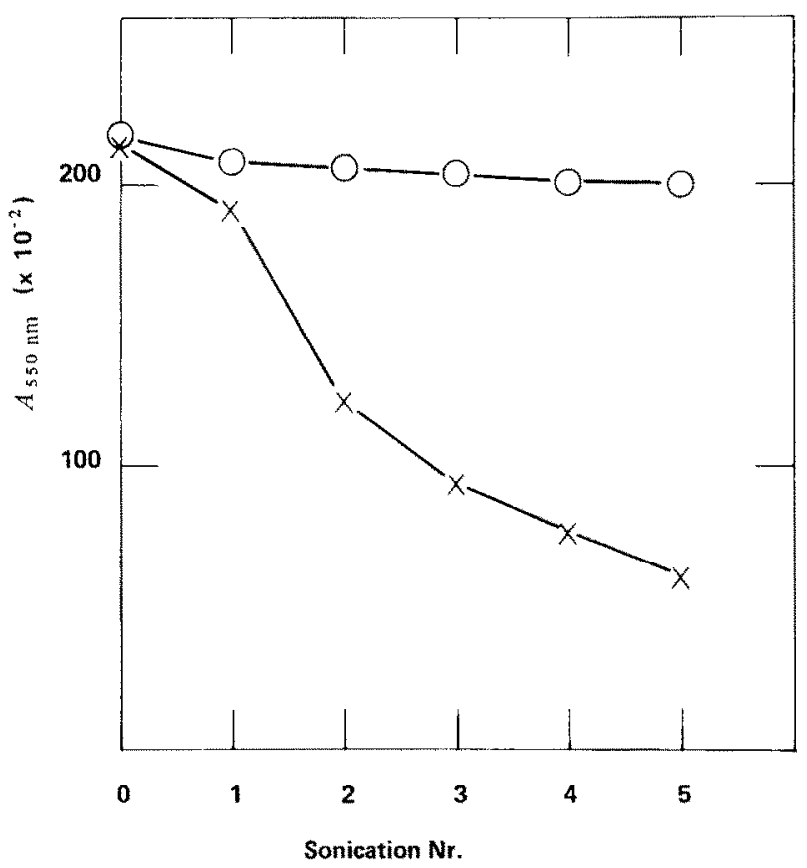

Fig. 1. Destruction of $B$. megaterium cells by ultrasonication. Cells were harvested from the early logarithmic growth phase $\left(A_{550} \mathrm{~nm}=0.360\right)(\mathrm{X})$ and at the end of the logarithmic growth $(0)$. The cells were suspended in the phosphate buffer to $A=0.210$ at $550 \mathrm{~nm}$. Ultrasonication was carried out with a Branson sonifier ( $60 \mathrm{~W}$ output) in 30 -s pulses with $1 \mathrm{~min}$ intervals. Samples were cooled in ice throughout. 'The figure shows the stability of cells harvested at the end of the logarithmic phase (O) and the rapid disintegration of cells harvested at the early growth stage (X).

zyme $(4.2 \mathrm{mg} / \mathrm{ml})$ was added and incubation at $37^{\circ} \mathrm{C}$ was performed until protoplast formation was complete as judged by phase-contrast microscopy.

A lipid extraction according to Bligh and Dyer [10] was carried out on whole cells and protoplasts of the four organisms. The results are summarized in Table I. Extraction is incomplete when whole cells are extracted. The residual phospholipid appears to be present in the cell residue which remains after the Bligh and Dyer extraction and can be dissolved only after lysozyme treatment of this residue. Identical results were obtained using the extraction procedures described by Folch [11] and Rose and Oklander [12].

The nature of the phospholipid which is retained within the cell residue was investigated by thin-layer chromatography [9] of lipid extracts obtained after lysozyme treatment of this residue. The results for $B$. megaterium are shown in Table II. It is obvious that cardiolipin is not extracted as long as the cell wall is present. Similar data were obtained with the other organisms under study (data not shown). One can envisage the possibility that cardiolipin is retained within the cell by a strong interaction with some intracellular constituents. To investigate this, the following experiments were car-

Fig. 2. Freeze-fracture electron microscopy of $B$. megaterium. Cells of $B$, megaterium were studied using freeze-fracture electron microscopy before (top) and after (bottom) lipid extraction. Before lipid extraction a fracture plane is observed typical for plasma membranes. The plasma membrane sturcture is lost during extraction; instead lipid vesicles (v) and remnants of the cell wall (w) and cytoplasm (c) can be seen. Magnification, X 100000 . Arrows indicate the directions of shadowing. 

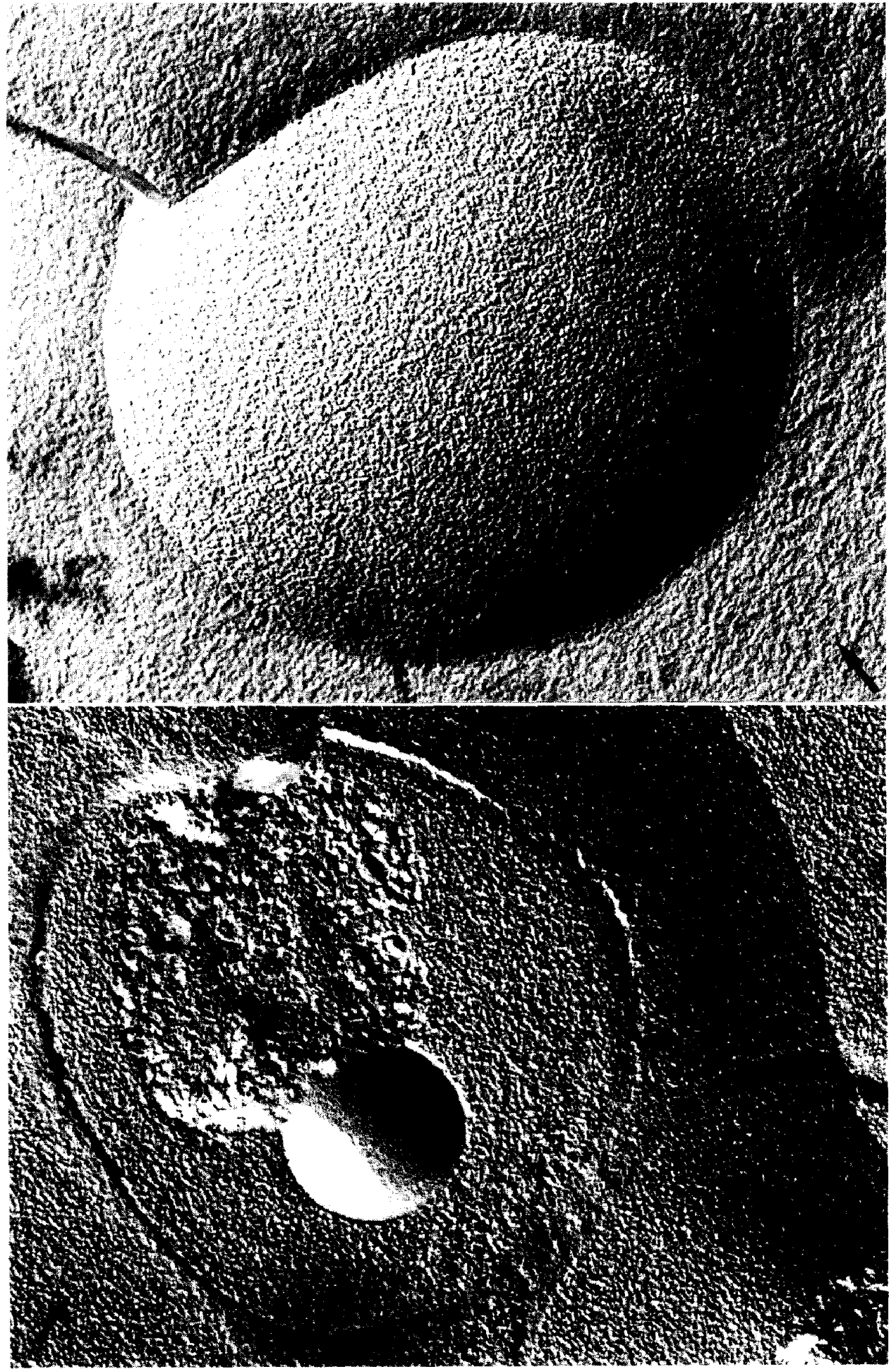
ried out. The cell residue remaining after one extraction step was dried, resuspended in buffer and incubated for $1 \mathrm{~h}$ at $37^{\circ} \mathrm{C}$ with one of the following compounds: EDTA (up to $50 \mathrm{mM}$ ); EGTA (up to $50 \mathrm{mM}$ ); toluene $(10 \%)$; deoxycholate $(0.05-0.4 \%)$; sodium dodecyl sulfate $(0.05 \%)$; trypsin $(1 \mathrm{mg} / \mathrm{ml})$; pronase $(1 \mathrm{mg} / \mathrm{ml})$; chymotrypsin $(1 \mathrm{mg} / \mathrm{ml})$; RNAase $(1 \mathrm{mg} / \mathrm{ml})$; DNAase $(1 \mathrm{mg} / \mathrm{ml})$ and various combinations of detergents and enzymes listed above. Then the residue was extracted for a second time but none of the entrapped cardiolipin could be recovered. It is indicated by these results that mucopeptide-teichoic acid layer forms the only barrier for cardiolipin extraction. This possibility is underlined by the following experiment. Cells, harvested in the early logarithmic growth phase $\left(A_{550 \mathrm{~nm}}=0.360\right)$ were compared with cells harvested at the end of the logarithmic growth $(A=$ 2.350 ). The former cells appeared to be surrounded by a thin cell wall as seen in electron microscopy (data not shown) and were fragile. Ultrasonication resulted in a rapid destruction of the cells (Fig. 1). Bligh and Dyer extraction of these cells resulted in complete extraction of all cardiolipin present. In contrast full grown cells did have a thick cell wall, were much more resistant against sonication and appeared to retain all of their cardiolipin within the cell during extraction. How such a barrier function of the cell wall is established is not known. However it can be speculated that the thick, highly polar, negatively charged layer prevents an effective penetration of the chloroform. This may result in a chloroform concentration within the cell which is too low to solubilize cardiolipin. The low solubility of this as well as other highly negatively charged phospholipids has been noted before [13]. The presence of acid in the extraction medium is known to increase the solubility of these phospholipids [13]. A similar observation was made in our studies. Extraction of whole cells or cell residues in the presence of $0.1 \mathrm{M} \mathrm{HCl}$ or acetic acid slightly enhanced the recovery of cardiolipin. Up to $20 \%$ of the total amount could be solubilized this way. That the low solubility of cardiolipin is responsible for its retention is shown furthermore by the observation that an increase in temperature at which the extraction is performed yields higher amounts of cardiolipin. At $45^{\circ} \mathrm{C}$ up to $50 \%$ can be extracted.

During extraction of whole cells the membrane structure is lost. That can clearly be visualized by freeze-fracture electron microscopy. The normally observed fracture plane through the plasma membrane (Fig. 2, top) is no longer seen; instead fracturing occurs through the cell interior. The cell wall contour as well as the remnants of the cytoplasm are clearly visible after lipid extraction (Fig. 2, bottom). In addition lipid vesicles can be observed adhering to or embedded in the cytoplasm. Most likely the non-extracted cardiolipin is present in these vesicles.

The data presented above explain the discrepancies which exist concerning the actual cardiolipin content of Gram ${ }^{+}$bacteria. Extraction of whole cells, when harvested from the late logarithmic or stationary phase, yields low recoveries of cardiolipin [3-7]. The true cardiolipin content can be estimated only after rupture of the cell wall. These observations are relevant in view of recent interests in the mechanisms of phospholipid biosynthesis in 
these organisms $[5,6]$. It is feasible that cardiolipin is a major phospholipid also in the strains of $B$. megaterium used in these experiments. If so, a number of observations, especially those regarding the high turnover of phosphatidylglycerol, which is considered to be the direct precursor of cardiolipin [14] might be easier to understand.

We thank Mrs. J. Leunissen-Bijvelt for carrying out freeze-fracture electron microscopy. This research was carried out with financial aid from The Netherlands Organization for the Advancement of Pure Research (Z.W.O.).

\section{References}

1 Ikawa, M. (1967) J. Bacteriol. 31, 54-64

2 Op den Kamp, J.A.F., van Deenen, L.L.M, and Tomasi, V. (1969) in Structural and Functional Aspects of Lipoproteins in Living Systems (Tria E. and Scancu, A.M., eds.), pp. 225-323 Academic Preșs, London

3 Op den Kamp, J.A.F., Houtsmuller, U.M.T. and van Deenen, L.L.M. (1965) Biochim. Biophys. Acta $106,438-441$

4 Rothman, J.E. and Kennedy, E.P. (1977) J. Mol. Biol. 110, $603-618$

5 Langley, K.E., Yaffe, M.P. and Kennedy, E.P. (1979) J. Bacteriol. 140, 996-1007

6 Lombardi, F.J. and Fulco, A.J. (1980) J. Bacteriol. 141,618-625

7 Eisenberg, A.D. and Corner, T.R. (1978) Can. J. Microbiol. 24, 386-396

8 Rilfors, L., Wieslander, A. and Stahl, S. (1978) J. Bacteriol. 135, 1043-1052

9 Demant, E.J.F., Op den Kamp, J.A.F. and van Deenen, L.L.M. (1979) Eur. J. Biochem. 95 , $613-619$

10 Bligh, E.G. and Dyer, W.J. (1959) Can. J. Biochem. Physiol. 37, $911-917$

11 Folch, J., Lees, M. and Sloane Stanley, G.H. (1957) J. Biol. Chem. 226, $497-509$

12 Rose, H.G. and Oklander, M. (1965) J. Lipid Res. 6, 428-431

13 Burton, R.M. (1972) in Fundamentals of Lipid Chemistry (Burton, R.M. and Guerra, F.C., eds.), pp. 11-31, B.I. Science International, Webster Grove, U.S.A.

14 Hirschberg, C.B. and Kennedy, E.P. (1972) Proc. Natl. Acad. Sci. U.S.A. 69, 648-651 